\title{
The influence of changes in the structure of electric power generation on the management of energetic waste in Poland
}

\author{
Justyna Pyssa ${ }^{1, a}$ \\ ${ }^{1}$ AGH University of Science and Technology, Faculty of Energy and Fuels, Al. Mickiewicza 30, 30-059 Kraków, Poland
}

\begin{abstract}
In the paper the changes in structure of production of electric power and heat in Poland has been analyzed. Both the quantity and quality of incineration byproducts is determined by the way of generation of energy and used raw materials. It also depends on the production volume. The possibility of economic utilization of energetic waste from various production sources requires detailed knowledge of its physicochemical composition, properties and vulnerability for further processing in various technologies. Economic directions of using byproducts from incineration is also discussed in detail.
\end{abstract}

\section{Introduction}

Hard coal, crude oil and natural gas are the basic carriers of the primary energy. The long-term forecast for Poland appears to show that the position of coal will be steadfast and remain at a high level for at least next several decades. The use of coal as the primary energy is connected with definite ecological effects. In the process of incineration of solid fuels, regardless of the applied technology, dusts, carbon monoxides, sulfur monoxides and nitrogen oxides are emitted into atmosphere. The generation of electrical energy and heat is intrinsically connected with producing significant amounts of waste - regular products of incineration intercepted in a form of fly ash in electrostatic precipitators and bottom ash (also called slag) shed from the deposit. Byproducts of incineration comprise valuable raw materials for many industry branches. Continuous technological changes which occur in the power industry significantly affect their variety which in turn means their physical and chemical parameters. The biggest number of studies regards the use of fly ashes from the hard coal which are generated in conventional pulverized-fuel boilers. Cinder from fluidized bad boilers and the brown coal as well as ashes from co-incineration of the hard coal and biomass are continuously examined and new solutions based on their use are sought.

\section{Industry of electric power production in Poland}

Polish sector of electric power generation relies mainly on the hard and brown coal - 80,89 percent (figure 1). The share of renewable energy sources is also significant and makes 12,15 percent - it is predominantly the wind energy. Other sources of energy are the natural gas with a share of 5,63 percent and the crude oil with a 1,36 percent stake. By analyzing changes in the production of electric power in the years 2008 - 2014 (figure 2) the largest increase was noted in technologies basing on the renewable energy - from 5,4 Mtoe in 2008 up to 8 Mtoe in 2014. By contrast, the share of energy generated from the hard and brown coal decreased substantially from 60,5 Mtoe in 2008 to 53,6 Mtoe in 2014.

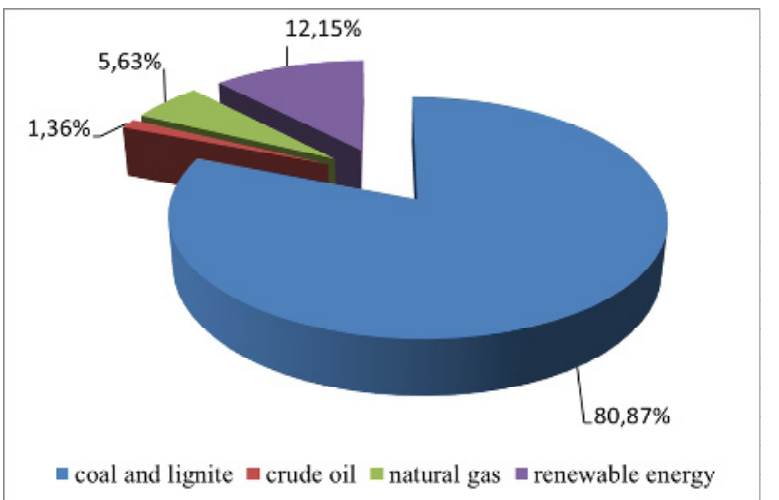

Figure 1. Structure of electric power generation in Poland (in percent) in 2014 (author's own research based on [1]).

Among thermal power plants, 15 power stations use the hard coal for the process of electrical energy production which comprises 65,2 percent of all power plants in that group. The brown coal is incinerated in 6 power stations, while two power plants use the biomass (table 1). A numerous group is created by combined heat and power stations - in a number of 85 , and commercial combined heat and power plants -68 .

\footnotetext{
${ }^{\text {a }}$ Corresponding author: jpyssa@agh.edu.pl
} 


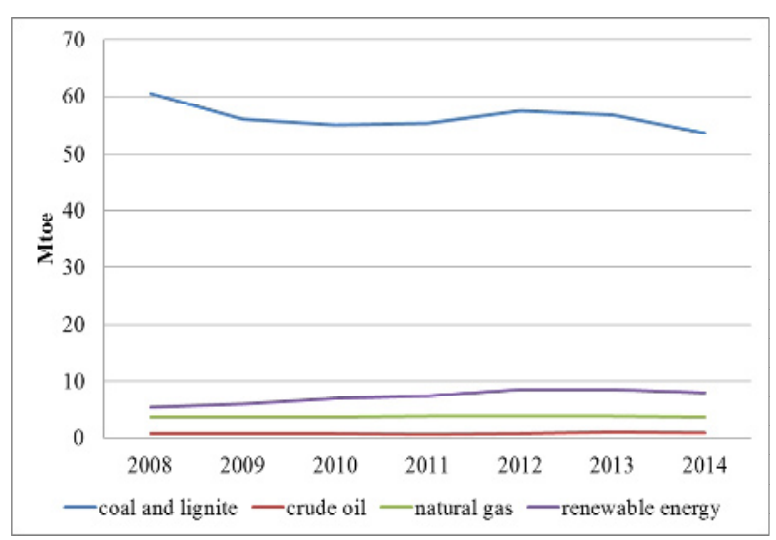

Figure 2. Production of energy in Poland in division by generation sectors (Mtoe) for the years 2008-2014 (author's own research based on [1]).

\section{Places of production}

The following table 2 and figure 3 present quantities (in thousand $\mathrm{Mg}$ ) of incineration by-products (according to the Waste Catalogue [3]) generated in particular types of power plants and combined heat and power stations in Poland in the year 2012.

Table 1. Sector of generation of electric power in Poland [2].

\begin{tabular}{|l|l|}
\hline Group name & Number \\
\hline Thermal power plants including: & 23 \\
\hline - operating on hard coal & 15 \\
\hline - operating on brown coal & 6 \\
\hline - operating on biomass & 2 \\
\hline Combined heat and power stations & 85 \\
\hline $\begin{array}{l}\text { Commercial combined heat and power } \\
\text { stations }\end{array}$ & 68 \\
\hline
\end{tabular}

In combined heat and power stations operating on gas three types of incineration by-products $-100101,1001$ 02 and 100103 - were produced in 2012 (their amount was 17,8 thousand $\mathrm{Mg}$ ). In power plants and combined heat and power stations operating on biomass 36,6 thousand $\mathrm{Mg}$ of incineration by-products from groups 10 $0101,100103,100124$ and 100182 were generated. Power plants operating on brown coal produced five types of waste: $100102,100105,100107,100180$ and 100182 (11 275,9 thousand $\mathrm{Mg}$ ). Power plants and combined heat and power stations operating on hard coal generate all sorts of waste from the analyzed groups.

\section{Physicochemical properties of incineration by-products}

Dynamic growth in quantities of production of incineration by-products is connected with the increase in demand for electric power which in Poland is mostly made of the hard and brown coal.
Table 2. Quantities and types of incineration by-products (thousand $\mathrm{Mg}$ ) generated in particular types of power plants in 2012 (author's own research based on [4].

\begin{tabular}{|c|c|c|c|c|}
\hline $\begin{array}{l}\text { Code of } \\
\text { wastet }\end{array}$ & \begin{tabular}{|l} 
Power plants \\
$\begin{array}{ll}\text { operzalizys } & \text { ou } \\
\text { broxtn enal }\end{array}$
\end{tabular} & $\begin{array}{l}\text { Power plants and combined } \\
\text { leeal and power statious } \\
\text { operating on hard cosal }\end{array}$ & $\begin{array}{l}\text { Combined heat and } \\
\text { power slativus } \\
\text { operating on gas }\end{array}$ & $\begin{array}{l}\text { Power plants and } \\
\text { combined heat and power } \\
\text { stations operating on } \\
\text { bicmass }\end{array}$ \\
\hline 100101 & 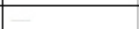 & 1715,0 & 10,3 & 0,6 \\
\hline 100102 & 1067,0 & 3950,6 & 7,4 & - \\
\hline 100103 & - & 5,6 & 0,1 & 21,3 \\
\hline 100105 & 257,8 & 472,1 & - & - \\
\hline 100107 & 218,1 & - & - & - \\
\hline 100117 & & 652,1 & & \\
\hline 100124 & - & 548,8 & - & 10.9 \\
\hline 100180 & 7480,3 & 8386,2 & - & - \\
\hline 100181 & - & 1,9 & - & - \\
\hline 100182 & 2252,7 & 1892.3 & - & 3.8 \\
\hline
\end{tabular}

where:

- means that the waste was not produced,

1 - numbers of codes in accordance with the Regulation of the Minister for the Environment as of the $9^{\text {th }}$ of December 2014 concerning the catalogue of waste (Journal of Laws 2014, item 1923) [3]

100101 - Bottom ash, slag and boiler dust (excluding boiler dust mentioned in 100104 )

100102 - Coal fly ash

100103 - Fly ash from peat and untreated wood

100105 - Calcium-based reaction waste from flue gas desulphurization in solid form

100107 - Calcium-based reaction waste from flue gas desulphurization in sludge form

100117 - Fly ash from co-incineration other than those mentioned in 100116

100124 - Sands from fluidized beds (excluding 1001 82)

100180 - Mixture of ash and slug from wet disposal of furnance waste

100181 - Microspheres from fly ashes

100182 - Mixtures of fly ashes and solid waste from calcium methods of desulphurization of waste gas (dry and semi-dry methods of desulphurization of flue gases as well as incineration in fluidized bed).

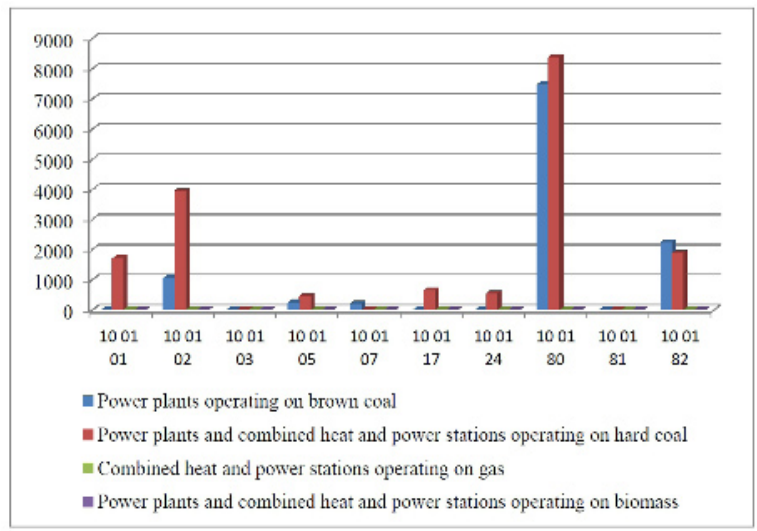

Figure 3. Amount (thousand $\mathrm{Mg}$ ) of generated incineration byproducts UPS in particular types of power plants in 2012 (author's own research based on [4]).

Depending on which type of coal is incinerated - hard or brown - the composition of fly ashes shows different 
puzzolan properties. Fly ashes obtained from brown coalfired boilers are of high calcium content amounting to 40 percent of mass and present much better puzzolan properties than fly ashes coming from the combustion of hard coal [5]. Ashes with low content of calcium consist mainly of aluminosilicate glaze. In those ashes from crystallized phases - sillimanite, mullite and quartz crystallize during cooling. And ferric oxides occur in a form of hematite and magnetite. It is believed that the high content of crystallized phases in the ash of that type decreases its puzzolan activities [6]. In all types of fly ashes the basic chemical elements are oxides of silicon, aluminum, ferric, calcium, magnesium, potassium, sodium and unburned coal. The components of glassy phase are predominantly $\mathrm{SiO}_{2}$ and $\mathrm{Al}_{2} \mathrm{O}_{3}[5,7$, 8]. The chemical composition of fly ashes with high and low content of calcium is placed in the table 3 .

Table 3. Variability of chemical composition of fly ashes with low and high calcium content [9].

\begin{tabular}{|l|l|l|}
\hline \multirow{2}{*}{$\begin{array}{l}\text { Compo- } \\
\text { nent }\end{array}$} & $\begin{array}{l}\text { Fly ash with low } \\
\text { calcium content }\end{array}$ & $\begin{array}{l}\text { Fly ash with high } \\
\text { calcium content }\end{array}$ \\
\cline { 2 - 3 }$\left[\begin{array}{|}|c| \\
{[\%}\end{array}\right.$ mass $]$ \\
\hline $\mathrm{SiO}_{2}$ & $34-60$ & $25-40$ \\
\hline $\mathrm{Al}_{2} \mathrm{O}_{3}$ & $17-31$ & $8-17$ \\
\hline $\mathrm{Fe}_{2} \mathrm{O}_{3}$ & $2-25$ & $5-10$ \\
\hline $\mathrm{CaO}$ & $0,5-5$ & $10-38$ \\
\hline $\mathrm{MgO}$ & $1-5$ & $1-3$ \\
\hline
\end{tabular}

In all sorts of fly ashes the essential chemical components are oxides: $\mathrm{SiO}_{2}, \mathrm{Al}_{2} \mathrm{O}_{3}$ and $\mathrm{CaO}$ (95-99\%). In ashes there are additionally side components in a form of: $\mathrm{MgO}, \mathrm{Na}_{2} \mathrm{O}, \mathrm{K}_{2} \mathrm{O}, \mathrm{SO}_{3}, \mathrm{P}_{2} \mathrm{O}_{5}, \mathrm{TiO}_{2} \quad(0,5-3,5 \%)$ and unburned coal (ignition losses) $[6,10]$. The content of coal in ashes is dependent on $[11,12]$ :

- particle size distribution of incinerated coal dustthe finer it is ground, the lower is the content of unburned coal,

- temperature and combustion time - the higher is the temperature and the longer is the combustion time, the lower are the losses on ignition,

- construction of furnace - bigger remains of coal usually occur in ashes obtained from fluidised boilers.

Ashes can contain trace quantities of such elements as: $\mathrm{Mn}, \mathrm{B}, \mathrm{Ba}, \mathrm{Cu}, \mathrm{Sr}, \mathrm{Ni}, \mathrm{Cr}, \mathrm{Zn}, \mathrm{Cd}, \mathrm{Co}, \mathrm{Mo}, \mathrm{V}, \mathrm{Se}, \mathrm{Pb}$, As and others $(0,1-0,3 \%)$ as well as radioactive elements ${ }^{40} \mathrm{~K},{ }^{226} \mathrm{Ra}$ and ${ }^{232} \mathrm{Th}[7,8,11-14]$. Radioactive elements do not exceed concentration which would prevent the economic use of incineration by-products [5, 14].

Over the past several years new type of energetic waste emerged in Poland - fly ashes from the biomass combustion. The chemical composition of those ashes depends on the type of incinerated material. They usually contain more alkaline compounds than ashes from the hard and brown coal combustion. Biomass can also be marked with lower calorific value and higher humidity which has influence on reducing the combustion temperature and results in lower content of glassy phase and increased content of unburned coal in fly ashes. Those ashes contain also lesser amounts of $\mathrm{SiO}_{2}$ and $\mathrm{Al}_{2} \mathrm{O}_{3}$. By contrast, the amount of $\mathrm{CaO}, \mathrm{K}_{2} \mathrm{O}$ and $\mathrm{P}_{2} \mathrm{O}_{3}$ increases decidedly. They can be most often marked by the lack of puzzolan properties and hydraulic activity [15].

\section{Directions of management of incineration by-products}

Incineration by-products are utilized in many branches of economy: in construction industry, ceramics, mining industry, land reclamation and agriculture. Directions of use of incineration by-products in Poland are placed in the table 4 .

Table 4. Directions of use of incineration by-products in Poland

\begin{tabular}{|c|c|}
\hline Branch & Utilization \\
\hline Mining industry & $\begin{array}{l}\text { Conducting fire prevention (insulation of } \\
\text { fire fields) } \\
\text { Mechanical reinforcement of rock mass } \\
\text { Backfilling of mine workings } \\
\text { Use in sealing works thanks to the high } \\
\text { porosity of binder }\end{array}$ \\
\hline $\begin{array}{l}\text { Construction } \\
\text { industry }\end{array}$ & $\begin{array}{l}\text { Additive to cement (sulphated component } \\
\text { carrier) as well as puzzolan additive } \\
\text { (increases tensile strength and resistance } \\
\text { against chemical corrosion) } \\
\text { Raw material for manufacturing artificial } \\
\text { aggregates } \\
\text { Production of cell concrete (aerated and } \\
\text { foam concrete) }\end{array}$ \\
\hline $\begin{array}{l}\text { Road and } \\
\text { engineering } \\
\text { works }\end{array}$ & $\begin{array}{l}\text { Applied in building landfills for waste } \\
\text { Used in ground stabilization in road works } \\
\text { Applied in flood-related sealing of sites } \\
\text { Material for building embankments }\end{array}$ \\
\hline $\begin{array}{l}\text { Land } \\
\text { reclamation }\end{array}$ & $\begin{array}{l}\text { Depending on the chemical composition } \\
\text { (lack of heavy metals) - used for } \\
\text { reclamation of excavation of clay raw } \\
\text { materials and others }\end{array}$ \\
\hline $\begin{array}{l}\text { Neutralization of } \\
\text { sewage and } \\
\text { sludge }\end{array}$ & $\begin{array}{l}\text { Thanks to high alkalinity are suitable for } \\
\text { neutralization of } \mathrm{pH} \text { value of sewage } \\
\text { High activity of calcium oxide included in } \\
\text { them allows to neutralize industrial sewage }\end{array}$ \\
\hline Agriculture & $\begin{array}{l}\text { Used for soil de-acidification due to } \\
\text { alkaline character }\end{array}$ \\
\hline Others & $\begin{array}{l}\text { Secondary sorbents (because of free lime in } \\
\text { their composition) }\end{array}$ \\
\hline
\end{tabular}

\subsection{Use of incineration by-products in construction industry}

Fly ashes are applied to a large extent in manufacturing of cement because of their puzzolan properties and amorphous silicic acid (silica) contained in the glassy part of ash [5, 8]. Most commonly they are used as active additives. Ashes are minced together with the Portland clinker through which, as a result of chemical reactions, functional features of adhesive alter leading to the occurrence of puzzolan cement [16]. The content of ash is between 5 to 14 percent of the total mass of raw material. The addition of ash influences not only the increase in cement mass, but first of all improves 
its frost resistance, resistance to aggressive chemicals and diminishes concrete shrinkage [17].

Ashes are widely used as raw materials for the production of clinker Portland cement. Fly ashes from the hard coal combustion replace a so-called 'low' material (that is such which calculated on the calcinated substance has less than 67 percent of $\mathrm{CaO}$ ) in the raw set and is a carrier of $\mathrm{Al}_{2} \mathrm{O}_{3}, \mathrm{Fe}_{2} \mathrm{O}_{3}$ and $\mathrm{SiO}_{2}$. The application of fly ashes as a low material allows to reduce the temperature of sintering by 200 to $300^{\circ} \mathrm{C}$. It causes the decrease in the use of technological fuel sometimes by 30 percent. Fly ashes are also widely used as a corrective addition. And so they can be utilized as silicon-bearing, iron-carrying and clay-bearing addition depending on particular oxides in the batch $[17$, $18]$.

One of the main ways of use of fly ashes is the manufacturing of concrete. Employing ashes causes the reduction in water demand and improves the plasticity of mixture. Ash and microfibre additives have a significant effect on lowering chemical corrosivity through material and structural protection of concrete composites. In the manufacture of cell concrete they are used as aggregates and partially as binders through which production costs are diminished [16].

Ashes are utilized in the production of building ceramics (solid bricks, hollow bricks, checker bricks, breezeblocks), fired ceramics, clinker products, sewer and sanitary ceramics. In the building ceramics industry fly ashes can be used as the basic raw material and as a weakening additive [8, 18]. The application of ashes as the primary raw material takes place in the so-called ash- based technology of manufacture of building ceramics where it replaces the natural loamy material and makes for 60 to 80 percent of brick mass.

\subsection{Road and engineering works}

The economic situation in the construction market especially in road works - provoked enormous demand for natural aggregates to which the aggregates produced from industrial waste became an alternative [19].

The manufacture of aggregates from fly ashes can be conducted with use of non-firing method (aggregates are obtained directly from ashes or by granulation of mixture of ashes and mineral binder). In case of firing method the material is granulated first and then fired.

Fly ashes are also used for land valorization. They drain, enhance carrying capacity of soil and make hydraulic or puzzolan factor which allows to bind land and achieve compressive strength and frost resistance $[20,21]$.

Siliceous and aluminous ashes from fluidized boilers are applied in road building for stabilization and land and base improvement for constructions and creating embankments $[5,22]$. Thanks to the high content of calcium, they are very suitable for the production of road binders which allow to stabilize lands and reduce costs of binders while obtaining the same stabilization parameters which are achieved by using clean cement or calcium [18]. Ashes belonging to siliceous ones can be characterized with low content of $\mathrm{CaO}(0,5-4,7 \%)$ and $\mathrm{SO}_{3}(0,3-2,9 \%)$ and are used as the substitute for cement in stabilizing substructure of roads with low car traffic and also for creating filtration and insulating layers and building of bodies of levees [5, 17, 22].

Due to the presence of radioactive isotopes (potassium K-40, radium Ra-226 and thorium Th-228) in natural ashes, the examination of samples is conducted on the basis of criteria included in the regulation of the Council of Ministers as of the $2^{\text {nd }}$ of January 2007 (Journal of Laws no 4, item 29) [23]. According to the criteria, incineration by-products fulfill requirements for industrial waste applied in ground construction works built in built-up areas or in areas intended for building in local spatial development plan and for leveling such areas [5].

\subsection{Use of incineration by-products in mining technologies}

Incineration by-products are also widely used in mining technologies. They are utilized for construction and filling purposes depending on their physicochemical properties [24-27]. Ashes delivered to coal mines are a raw material base for the manufacture of ash-andwater mixtures in mining backfilling installations $[5,18$, 26-28]. The mixtures are transported through pipes from the surface to underground mine workings and used mainly within the frames of fire and methane prevention in backfilling and sealing of mine voids [25, 29].

To the main uses of incineration by-products in mining technologies belong $[5,25-27,30]$ :

- fire and methane prevention (through sealing and backfilling of gobs which prevents the occurrence of endogenous fires and mitigates the danger of releasing methane and other gases from gobs

- insulation of fire fields and closed mine workings through manufacture of insulating backfilling cork

— backfilling of post-mining voids and mechanical enforcement of rock mass which has impact on reducing the size of the surface deformation

- simplification of ventilation systems in mines through manufacture of insulating and explosion proof cork.

\subsection{Use in agriculture}

In agriculture there is predominant use of fly ashes from hard coal $[14,31]$. They are used as calcium and magnesium fertilizers for soil fertilization $[7,8,16$, 31-34]. They improve physicochemical properties, increase the capacity of absorbent complex, enhances the absorbency to water, and reduce the density and alkalize acidic soils [7, 14, 17, 32, 34, 35].

\section{Summary}

The state of technological knowledge, which we currently possess, allows for a very wide range of the use of waste (10 01) which comes from power plants. The characteristics one should pay special attention to is the fact that the waste successfully replaces such natural raw materials as gravel and sand the extraction of which causes degradation to the natural environment. 
Adding such components not only influences positively the properties of concrete, but also limits the use of natural resources in an easy way.

The future demand for incineration by-products in Poland will be determined to a large extent by changes occurring in the domestic sector of electric power generation. Taking into consideration the current age structure of production units (more than 60 percent of the total power of boilers is installed in equipment which has been working for over 30 years) and stringent environmental standards arising from European directives, one should expect the execution of investments in new powers in the coming years. It is also necessary from the point of view of security of electric energy supply. Possessing considerable, as for European conditions, resources of hard and brown coal may be an argument for investing in new powers based on those energy carriers. Parallel to fulfilling commitments resulting from the climate and energy package, further growth of power in renewable energy sources will be essential.

Summarizing, incineration by-products are a precious raw material for many industry branches. Continuous technological changes taking place in energy economics significantly influence their diversity and in consequence physicochemical parameters - example in here are fly ashes from coal with admixture of co-incinerated biomass. Taking into account the adopted aim of diversification of domestic fuel and energetic structures in existing country's energy policy, one can state that the supply of typical products of hard and brown coal combustion (ashes and slag) will slightly decrease over the course of the next ten years.

\section{Acknowledgments}

The work is financed within the frames of statutory research no 11.11.210.213 at the Faculty of Energy and Fuels.

\section{References}

1. Eurostat, Energy, transport and environment indicators

http://ec.europa.eu/eurostat/en/web/productsstatistical-books/-/KS-DK-15-001

2. Agencja Rynku Energii, Statystyka elektroenergetyki polskiej (2013)

3. Regulation of the Minister for the Environment as of the $9^{\text {th }}$ of December 2014 concerning the catalogue of waste (Journal of Laws 2014, item 1923)

4. Agencja Rynku Energii. Emitor 2012. Emisja Zanieczyszczeń Środowiska w Elektrowniach $i$ Elektrociepłowniach Zawodowych (2013)

5. J. Pyssa, J. Rokita, Przegląd Górniczy 68(12), 132138

(2012)

http://yadda.icm.edu.pl/yadda/element/bwmeta1.ele ment.baztech-e36b801d-f368-442d-87331763 ec5f83bf

6. J. Filipiak, Annual Set The Environment Protection 13, 1043-1054 (2011) http://ros.edu.pl/images/roczniki/2013/pp_2013_078. pdf

7. N.L. Ukwattage, P.G. Ranjith, M. Bouazza, Fuel 109, 400-408 (2013) doi:10.1016/j.fuel.2013.02.016

8. Z.T. Yao, X.S. Ji, P.K. Sarker, J.H. Tang, L.Q. Ge, M.S. Xia, Y.Q. Xi, Earth-Science Rev. 141, 105-121 (2015) http://dx.doi.org/10.1016/j.earscirev.2014.11.016

9. S. Grzeszczyk, G. Lipowski, Popioły lotne $i$ ich wptyw na reologię $i$ hydratacje cementów. (Wydawnictwo Politechniki Opolskiej. Opole, 2002)

10. P. Iwanek, I. Jelonek, Z. Mirkowski, Min. Res. Manag. 24(4), 91-104 (2008) https://minpan.krakow.pl/Wydawnictwa/GSM2444/06-iwanekjelonek-mirkowski.pdf

11. A. Gonet, S. Stryczek, R. Wojciechowski, Drilling Oil and Gas 22(2), 551-558 (2005) http://journals.bg.agh.edu.pl/WIERTNICTWO/200502/W 2005 2 04.pdf

12. S.M. Shaheen, P.S. Hooda, Ch.D. Tsadilas, J. Environ. Manage 145, 249-267 (2014) doi: 10.1016/j.jenvman.2014.07.005.

13. D.K. Szponder, K. Trybalski, Górnictwo i Geoinżynieria 33(4), 287-298 (2009) http://yadda.icm.edu.pl/baztech/element/bwmeta1.ele ment.baztech-article-AGHM-00080032/c/Szponder.pdf

14. Z. Ciećko, A. C. Żołnowski, M. Madej, G. Wasiak, J. Lisowski, E. Rolka, Polish J. Soli Sci. XLVIII(1), 112 (2015) DOI: 10.17951/pjss/2015.48.1.1

15. M. Gawlicki, J. Małolepszy, Nowoczesna Gospodarka Odpadami, 1-2(8), 14-20 (2015) http://www.egospodarkaodpadami.pl/rynek/wykorzystanieodpadow-przemyslowych/

16. R.S. Blissett, N.A. Rowson, Fuel 97, 1-23 (2012) http://dx.doi.org/10.1016/j.fuel.2012.03.024

17. D.K. Szponder. Badania wybranych właściwości popiołów lotnych z zastosowaniem analizy obrazu. Rozprawa doktorska (AGH, Kraków 2012) winntbg.bg.agh.edu.pl/rozprawy2/10519/full10519.p df

18. M. Ahmaruzzaman, Progress in Energy and Combustion Science. 36, 327-363 (2010) http://www.sciencedirect.com/science/article/pii/S03 60128509000604

19. J. Pyssa, Przegląd górniczy, 66(5), 38-44 (2010) http://yadda.icm.edu.pl/baztech/element/bwmeta1.ele ment.baztech-article-BGPK-2859-1183

20. G. Rolka, E. Ślęzak, Prace Instytutu Ceramiki i Materiałów Budowlanych. 9, 148-155. (2012) http://yadda.icm.edu.pl/yadda/element/bwmeta1.ele ment.baztech-article-BTB6-0004-0044

21. A. Gruchot, T. Zydroń, Annual Set The Environment Protection. 15, 1719-1737 (2013) http://ros.edu.pl/images/roczniki/2013/pp 2013 115.pdf

22. J. Pyssa, Mineral Resources Management. 21(3), 83-93 http://www.meeri.eu/Wydawnictwa/GSM213/pyssa. pdf 
23. Regulation of the Council of Ministers as of the $2^{\text {nd }}$ of January 2007 (Journal of Laws no 4, item 29)

24. F. Plewa, M. Popczyk, P. Piontek, Energy Policy Journal 12(2), 485- 495 (2009). http://www.minpan.krakow.pl/se/pelne teksty $23 / \mathrm{k} 23 \mathrm{z} \_\mathrm{pe} / \mathrm{k} 23$ plew a popczyk piontek_z.pdf

25. Zając A., Madaj M., Energetyka 3, 143-146 (2010) http://yadda.icm.edu.pl/yadda/element/bwmeta1.ele ment.baztech-article-BPS1-0040-0044

26. F. Plewa, M. Popczyk, A. Zając, P. Pierzyna, Energy Policy Journal 15(3), 147-157 (2012) http://www.minpan.krakow.pl/se/pelne teksty26/k26pe3/k26pe3 ple wa inni 1 z.pdf

27. F. Plewa, M. Popczyk, P. Pierzyna, Energy Policy Journal 16(4), 257-270 (2013) http://yadda.icm.edu.pl/baztech/element/bwmeta1.ele ment.baztech-dc62e6fd-04c9-4341-8b5527d6b510800c/c/plewa.pdf

28. Z. Piotrowski, Utilization of fine-grained waste in underground coal mining (Archives of Mining Sciences, Kraków 2011)

29. J. Palarski, Przegląd górniczy 65(10), 45-51 (2009) http://yadda.icm.edu.pl/yadda/element/bwmeta1.ele ment.baztech-article-BGPK-2717-0582

30. Z. Piotrowski, Mineral Resources Management
24(4/1),
113-121
(2008)

http://www.meeri.pl/Wydawnictwa/GSM2441/piotro wski.pdf

31. E.J. Bielińska, S. Baran, S. Stankowski, Inż. Roln. 6(115), 7-15, 2009. http://ir.ptir.org/artykuly/pl/115/IR(115) 2525 pl.pd f

32. V.C. Pandey, N. Singh, Agriculture, Ecosystems and Environment. 136, 16 - 27 (2010) http://www.sciencedirect.com/science/article/pii/S01 67880909003442

33. L.C. Ram, R.E. Masto, Journal of Environmental Management 91, $603-617$ (2010) DOI: 10.1016/j.jenvman.2009.10.004

34. H.A. Mupambwa, E. Dube, P.N.S. Mnkeni, S. Afr. J.
Sci.
111(7-8),
1-6
(2015) http://dx.doi.org/10.17159/sajs.2015/20140103

35. D.K. Szponder, K. Trybalski TEKA Kom. Mot. Energ. Roln. - OL PAN 11, 373-385 (2011) http://yadda.icm.edu.pl/yadda/element/bwmeta1.ele ment.agro-0a9c223c-7437-4dfb-90dbcfb17ae46a89/c/373 teka_11_2011.pdf 